\title{
Patterns of abundance and size across varying spatial scales for the coral reef sponge Coscinoderma matthewsi
}

\author{
Alan R. Duckworth ${ }^{1,2,3, *}$, Carsten W. Wolff ${ }^{1,2}$, Heidi Luter ${ }^{1,2}$ \\ ${ }^{1}$ Australian Institute of Marine Science, PMB 3, Townsville, Queensland 4810, Australia \\ ${ }^{2}$ Australian Institute of Marine Science at James Cook University, Post Office James Cook University, Townsville, \\ Queensland 4811, Australia \\ ${ }^{3}$ Present address: Blue Ocean Institute, PO Box 250, East Norwich, New York 11732, USA
}

\begin{abstract}
Spatial variability in abundance and size of sponges are poorly understood compared with other sessile organisms such as corals. A hierarchical survey design across 3 spatial scales sites nested in locations nested in island groups - examined variation in sponge size and abundance for the common coral reef sponge Coscinoderma matthewsi (Lendenfed, 1886) (Demospongiae: Dictyoceratida) in Torres Strait, northern Australia. The abundance of C. matthewsi differed significantly across all 3 spatial scales, varying greatly between sites $200 \mathrm{~m}$ apart up to island groups $60 \mathrm{~km}$ apart. The size frequency distributions of $C$. matthewsi varied between sites and island groups, and were positively skewed with populations dominated by small sponges. There was no relationship between sponge abundance and size within and between island groups for C. matthewsi in Torres Strait.
\end{abstract}

KEY WORDS: Sponge $\cdot$ Abundance $\cdot$ Size frequency distribution $\cdot$ Spatial variation $\cdot$ Coscinoderma matthewsi

Resale or republication not permitted without written consent of the publisher

\section{INTRODUCTION}

Sponges are a dominant and diverse phylum in coral reefs (Reiswig 1973, Wilkinson \& Cheshire 1989) and can positively and negatively interact with the wider community in numerous ways, from providing food and shelter (Randall \& Hartman 1968, Dunlap \& Pawlik 1998) to occupying substratum excluding spatial competitors (Aerts 1998). Being efficient filter feeders of small particulate matter, coral reef sponges also represent an important energy coupling between the benthic and pelagic communities (Reiswig 1971, Lesser 2006).

Interactions with the coral reef community are influenced by sponge abundance and size frequency patterns, which can vary between species across small and large spatial scales (Wilkinson \& Cheshire 1989, Wilkinson \& Evans 1989, Duckworth \& Wolff 2007b). Variation in size and abundance across space is mediated by abiotic and biotic factors that can affect all life stages of a sponge, from water flow direction and speed influencing the dispersal of reproductives (Maldonado \& Young 1996) to disease causing partial mortality and decreasing size (Ayling 1981). In contrast to the numerous studies that have investigated variation of abundance and size across space for coral species (e.g. Meesters et al. 2001, Vermeij \& Bak 2003, Richardson \& Voss 2005), spatial variation has received less attention for coral reef sponges (e.g. Reiswig 1973, Trautman et al. 2000).

The coral reef sponge Coscinoderma matthewsi (Lendenfeld, 1886) is a massive, hemispherical sponge, grayish black in colour and can grow over $50 \mathrm{~cm}$ in length (Bergquist 1995, Duckworth \& Wolff 2007b). It is a heterotrophic species (Wilkinson 1983) that obtains its energy from filtering suspended food particles. Coscinoderma matthewsi has a widespread distribution, recorded from the eastern Indian Ocean (Fromont 2003) to the central Pacific Ocean (Bergquist 1995). On some coral reefs, C. matthewsi is a dominant sponge in 
terms of biomass, with $>10$ large individuals $20 \mathrm{~m}^{-2}$ (Duckworth \& Wolff 2007b). C. matthewsi is found in the central and eastern regions of Torres Strait (Duckworth et al. 2008) and is commercially farmed in Torres Strait and Micronesia for its high quality spongin fibres (MacMillan 1996, Duckworth \& Wolff 2007a). In the present study, we examine spatial variation in abundance and size of C. matthewsi in Torres Strait, which contains an archipelago of islands and reefs between northern Queensland, Australia, and Papua New Guinea.

\section{METHODS}

Study area and sampling strategy. The study area in Torres Strait is situated between Papua New Guinea and northern Queensland, Australia, and is bordered by the Warrior Reefs to the west and the edge of the continental shelf to the east (Fig. 1). Surveys for Coscinoderma matthewsi were done at 5 island groups: Ugar (Stephen Island) and Erub (Darnley Island) in eastern Torres Strait and Masig (Yorke Island), Poruma (Coconut Island) and Warraber (Sue Island) in central Torres Strait (Fig. 1). The island groups were, on average, $66 \pm 11$ (SE) km apart from each other. All surveyed islands are small and enclosed by fringing coral reefs. The reef slope generally starts at a depth of about $5 \mathrm{~m}$ (mean low water) and stops at $15 \mathrm{~m}$, descending at an angle from 20 to $60^{\circ}$. Maximum depth between neighbouring islands and reefs is

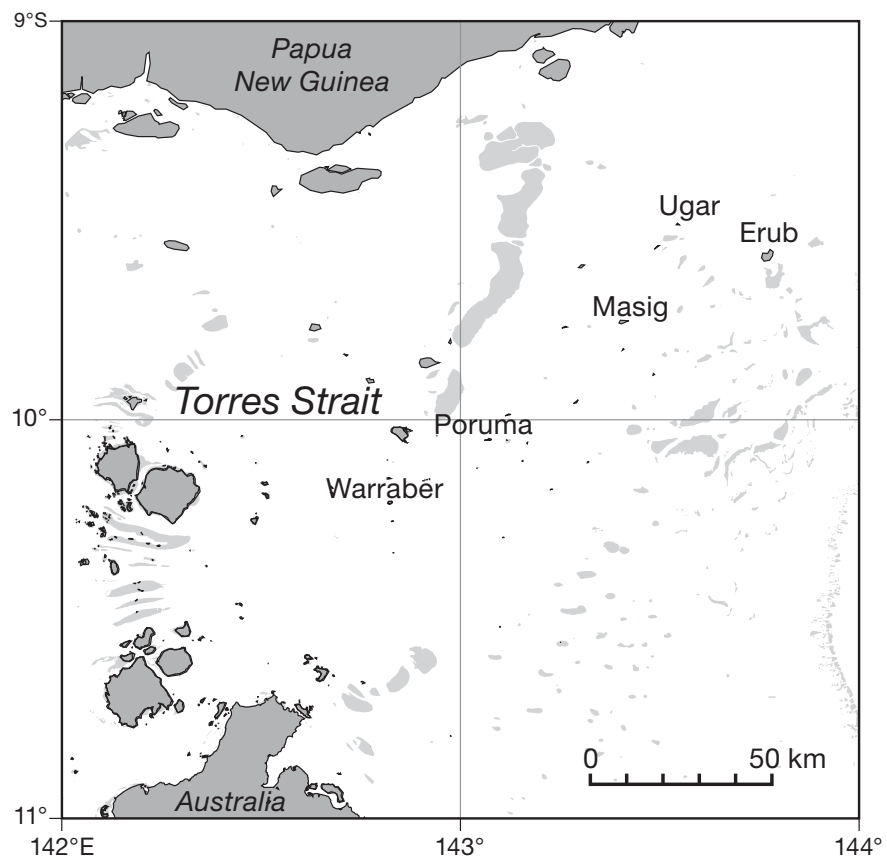

Fig. 1. Study area in Torres Strait. The major island is located directly under the name of each island group approximately $30 \mathrm{~m}$, with the substrate consisting of muddy sand (Harris 1988).

Sponge surveys were done at 7 or 8 randomly selected locations in each island group, with each location being $\geq 2 \mathrm{~km}$ apart, averaging $8 \mathrm{~km}$ separation. Each location was divided into 2 sites, approximately $200 \mathrm{~m}$ apart. At each site, three $30 \times 1 \mathrm{~m}$ strip transects were quantitatively surveyed for Coscinoderma matthewsi. Transects were separated by at least $20 \mathrm{~m}$ to retain independence and all were done between 7 and $12 \mathrm{~m}$, a depth where C. matthewsi is common in Torres Strait (Duckworth \& Wolff 2007b). To examine size frequency distributions patterns, the greatest dimension of every $C$. matthewsi was measured by a ruler attached to the dive slate and recorded. All surveys were done in November 2006, thus preventing any possible temporal variation in sponge size and abundance influencing the results.

Data analysis. Abundance of Coscinoderma matthewsi across spatial scales was analysed using a nested ANOVA, with island group as a fixed factor, and location and site as nested factors. To meet assumptions of ANOVA, data were $\log (x+1)$ transformed and island groups with $<25$ sponges were not included in the analysis. The Tukey-Kramer multiple comparison (TKMC) test was used to determine which island groups differed from each other in sponge abundance and size.

Sponge size was compared among island groups using 1-way ANOVA. Only island groups with > 25 recorded sponges were analysed to reduce the probability of a Type I error occurring due to different sample sizes (Zar 1999). Data was log transformed. For each island group, mean sponge size, SD, 95th percentile and coefficient of variation (CV) were calculated on raw untransformed data. Because the maximum size of sessile invertebrates can be influenced by chance events, the 95th percentile was used to compare the upper size limit across space (Soong 1993, Meesters et al. 2001). The CV is a measure of the variation in a population irrespective of mean size. Sponge size for each island group was also analysed using single Kolmogorov-Smirnov tests with Lilliefors adjustment $(p>0.05)$ to determine whether the size data have a normal distribution. To ensure that each test had a similar statistical power, 50 Coscinoderma matthewsi individuals were randomly selected if sample number from an island group exceeded 60 sponges. Skewness $\left(g_{1}\right)$ values were calculated as well, with a positive value indicating a greater proportion of small individuals and a negative value indicating that the population is dominated by large individuals. For each island group, Kolmogorov-Smirnov and skewness tests were done on both raw and log-transformed data, to determine whether a log transformation can normalise 
the size data for a sponge as shown for hard coral species (Bak \& Meesters 1998, Vermeij \& Bak 2003).

To investigate variation in size distribution over small spatial scales, sponge size was analysed in the island group where Coscinoderma matthewsi was most abundant using a nested ANOVA, with location as a fixed factor and site nested. Data was log transformed. Only locations where both sites had more than10 individuals were analysed to reduce the likelihood of a Type I error. For each analysed site, mean sponge size, $\mathrm{SD}$, 95th percentile and CV were calculated.

To examine the relationship between sponge abundance and size in Torres Strait, simple linear regression was done using sponge number and mean size at each site where Coscinoderma matthewsi was present. Data from transects were pooled to site to increase precision of mean size. Simple linear regression also compared sponge number to mean size at the island group where C. matthewsi was most abundant; data were compared among transects.

\section{RESULTS}

\section{Spatial variability in sponge abundance}

Coscinoderma matthewsi was found at all 5 island groups (Fig. 2). In total, 436 individuals were counted and measured during the survey. However, Warraber had low numbers of $C$. matthewsi and was excluded from the statistical analysis. The abundance of $C$. matthewsi varied significantly among island groups in Torres Strait (nested ANOVA: $F_{3,26}=9.94 ; \mathrm{p}<0.001$ ), being most abundant at Masig with $5.5 \pm 0.7$ (SE) sponges $30 \mathrm{~m}^{-2}$ on average (Fig. 2). In contrast, mean abundance $( \pm$ SE) was similar according to the TKMC test among Ugar, Erub and Poruma being $1.7( \pm 0.3)$, $1.1( \pm 0.2)$ and $1.2( \pm 0.4)$ sponges $30 \mathrm{~m}^{-2}$, respectively. At Warraber, mean abundance was $0.5( \pm 0.1) C$. matthewsi per transect.

Sponge abundance varied significantly among locations within each island group (nested ANOVA: $F_{26,30}=$ $1.93 ; \mathrm{p}=0.042$ ). At Erub and Poruma, for example, Coscinoderma matthewsi was relatively common at some locations but not recorded at neighbouring locations a few $\mathrm{km}$ away (Fig. 2). Among the 7 locations at Masig, mean abundance ranged from 0.8 to 8.8 sponges $30 \mathrm{~m}^{-2}$. The abundance of $C$. matthewsi also varied significantly among sites (nested ANOVA: $F_{30,120}=2.28$; $\mathrm{p}<0.001$ ). In some locations at Ugar, Erub and Poruma, C. matthewsi was found at one site but not recorded $200 \mathrm{~m}$ away (Fig. 2). In locations where C. matthewsi was recorded at both sites, density could vary by a factor of 10. Almost the half of the locations (11 of 24) with $\geq 5$ C. matthewsi present had $>75 \%$ of its indi-
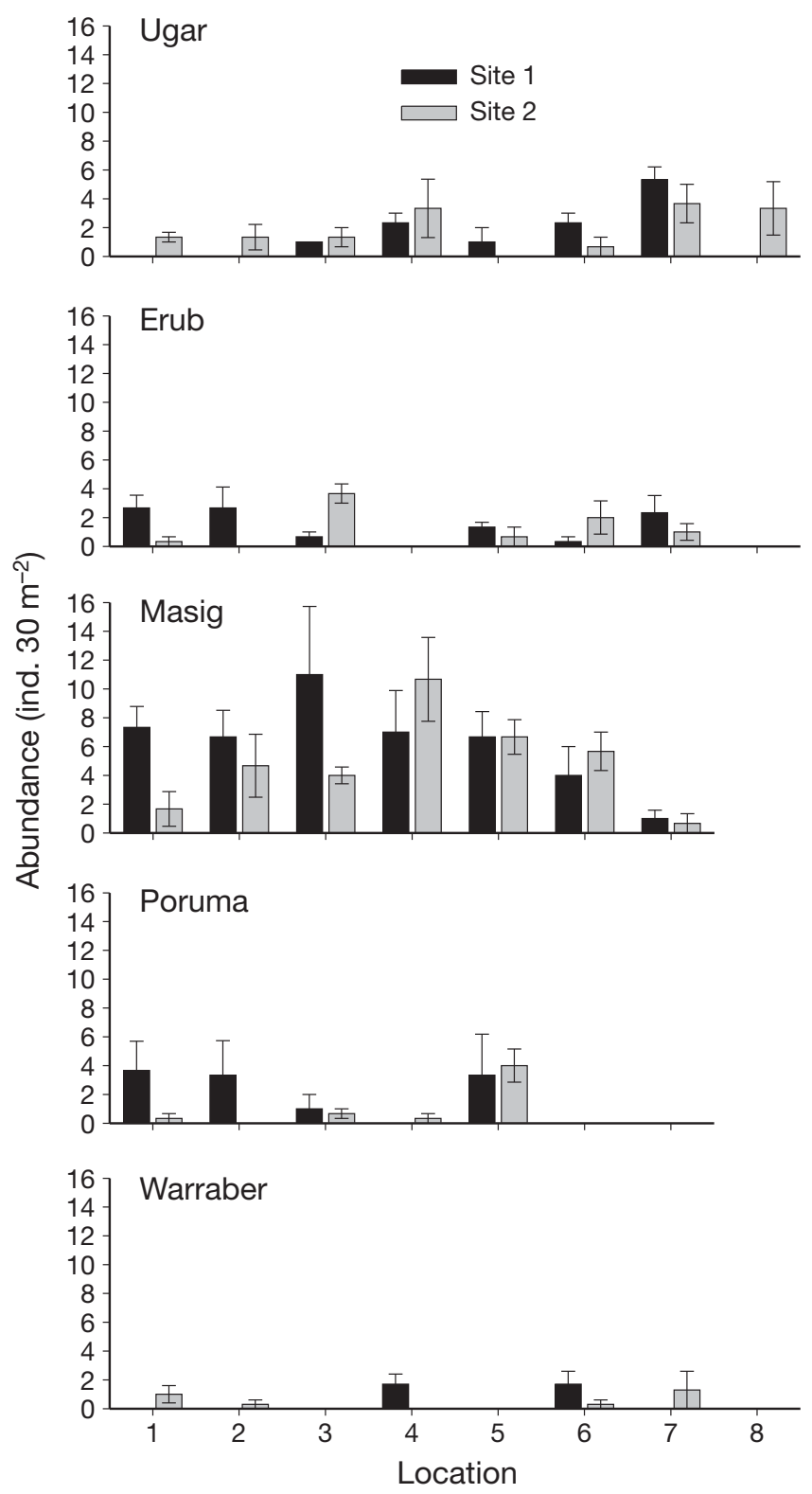

Fig. 2. Coscinoderma matthewsi. Mean abundance at each island group with nested sites and locations. Error bars represent variation between transects at a site $( \pm 1 \mathrm{SE})$

viduals recorded from 1 site. Variation in C. matthewsi abundance between neighbouring sites was therefore a common phenomenon in Torres Strait.

\section{Spatial variability in sponge size among island groups}

The size frequency distribution of Coscinoderma matthewsi varied significantly among island groups in Torres Strait (1-way ANOVA: $F_{3,414}=16.93 ; \mathrm{p}<$ 
0.0001). The TKMC test determined that sponge size was similar between Masig and Poruma, and between Ugar and Erub (Table 1, Fig. 3). At Warraber, which was excluded from the statistical analysis because of low sponge abundance, mean length was similar to that at Ugar and Erub (Table 1). Size results for the 95th percentile showed a similar pattern, being highest at Masig and Poruma and smallest at the 3 remaining island groups. At Masig and Poruma, C. matthewsi could be expected to grow to $>20 \mathrm{~cm}$ in length. The CV varied little among the island groups (Table 1), indicating that variation around the mean was similar throughout Torres Strait.

The Kolmogorov-Smirnov normality test on raw size data was significant for Ugar, Erub and Masig (Table 1), indicating that the untransformed size structure of Coscinoderma matthewsi at 3 of the 5 island groups did not have a normal distribution. After a log transformation, the size structure at Ugar, Erub and Masig became normally distributed. The untransformed size distributions at all island groups were positively skewed, indicating that small individuals dominate the $C$. matthewsi population at each island group. The proportion of small individuals $(<5 \mathrm{~cm})$ was greatest at Ugar (32\%), Erub (37\%) and Warraber (47\%) and lowest at Masig (14\%) and Poruma (8\%). Logtransforming the size data reduced the level of skewness ( $g_{1}$ value closer to 0 ) at 4 of the 5 island groups. The one exception was at Poruma, where the raw untransformed size data had a normal distribution and was only slightly positively skewed (Table 1).

\section{Spatial variability in sponge size among locations and sites}

At Masig, the size frequency distribution of Coscinoderma matthewsi was similar between locations (nested ANOVA: $F_{4,5}=0.93 ; \mathrm{p}=0.515$ ); 2 Masig locations were excluded from the analysis because $<10$ sponges were recorded from at least 1 site. Size pat-

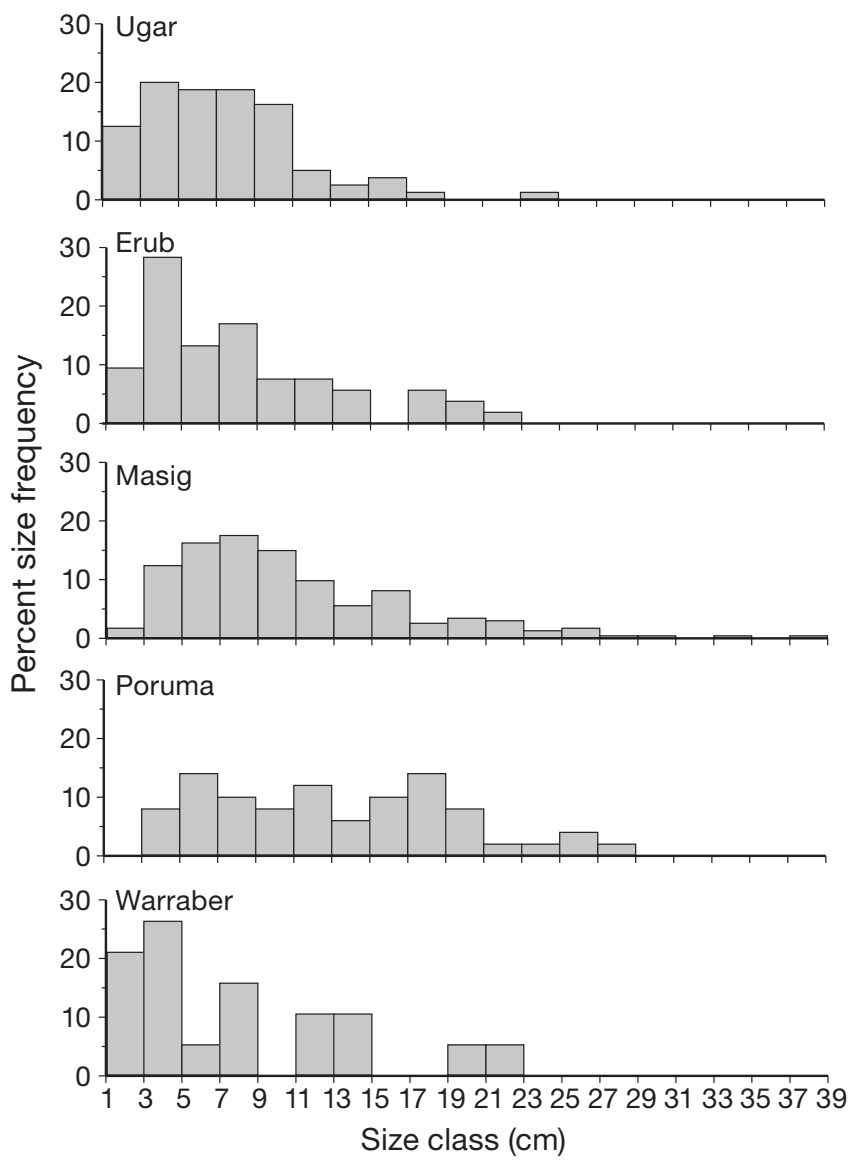

Fig. 3. Coscinoderma matthewsi. Size frequency distributions between island groups

terns for C. matthewsi varied significantly, however, between sites nested within locations (nested ANOVA: $F_{5,191}=4.27 ; \mathrm{p}=0.001$ ), indicating that size frequency distributions can vary greatly over short distances $(\sim 200 \mathrm{~m})$. At Location 2, for example, $60 \%$ of $C$. matthewsi sponges at Site 1 were $>10 \mathrm{~cm}$ while $>90 \%$ of individuals at Site 2 were $<10 \mathrm{~cm}$ (Fig. 4). A greater proportion of large sponges at Site 1 resulted in mean size and 95th percentile values double that recorded

Table 1. Coscinoderma matthewsi. Size distribution variables in each island group giving sample number (N), mean size, SD, coefficient of variation (CV) and the 95th percentile (95th); all measurements in $\mathrm{cm}$. Also shown are results from the single Kolmogorov-Smirnov normality test $(\mathrm{KS})$ and skewness $\left(\mathrm{g}_{1}\right)$ tests for untransformed and $\log (x+1)$ transformed data. Probability for KS either non-significant (ns) or significant $(<0.05)$

\begin{tabular}{|c|c|c|c|c|c|c|c|c|c|}
\hline \multirow[t]{2}{*}{ Island group } & \multirow[t]{2}{*}{$\mathrm{N}$} & \multirow[t]{2}{*}{ Mean } & \multirow[t]{2}{*}{$\mathrm{SD}$} & \multirow[t]{2}{*}{$\mathrm{CV}$} & \multirow[t]{2}{*}{ 95th } & \multicolumn{2}{|c|}{ Untransformed data } & \multicolumn{2}{|c|}{ Log-transformed data } \\
\hline & & & & & & KS & $g_{1}$ & $\mathrm{KS}$ & $g_{1}$ \\
\hline Ugar & 81 & 6.9 & 4.1 & 0.6 & 15.0 & $<0.05^{\mathrm{a}}$ & 1.24 & $\mathrm{~ns}^{\mathrm{a}}$ & -0.29 \\
\hline Erub & 53 & 7.6 & 5.2 & 0.7 & 18.4 & $<0.05$ & 1.08 & ns & 0.09 \\
\hline Masig & 233 & 10.3 & 6.1 & 0.6 & 22 & $<0.05^{\mathrm{a}}$ & 1.22 & $\mathrm{~ns}^{\mathrm{a}}$ & 0.07 \\
\hline Poruma & 50 & 12.7 & 6.4 & 0.5 & 24.1 & ns & 0.34 & ns & -0.42 \\
\hline Warraber & 19 & 7.5 & 6.1 & 0.8 & 20.1 & ns & 0.96 & ns & -0.01 \\
\hline
\end{tabular}




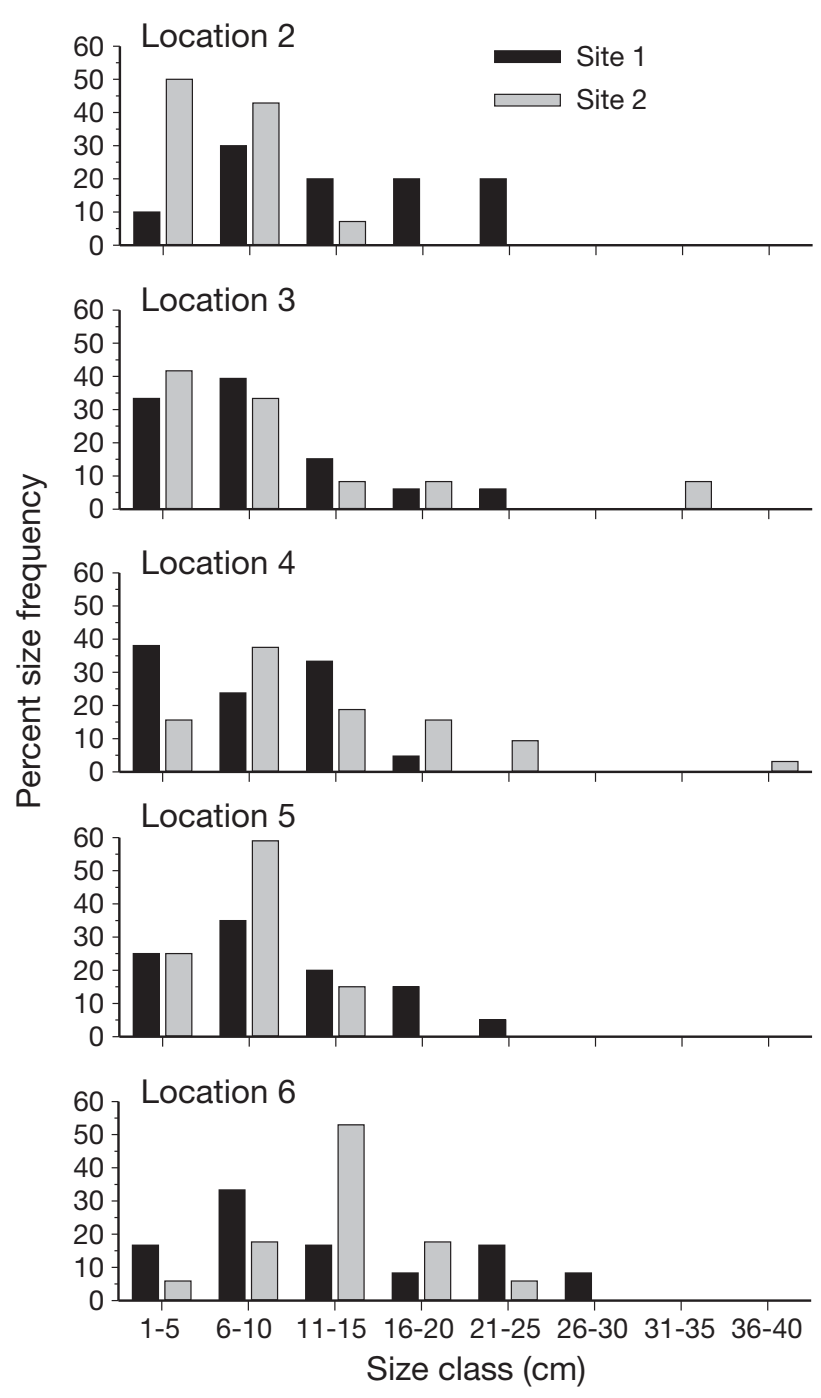

Fig. 4. Coscinoderma matthewsi. Size frequency distributions between sites and locations at Masig

from Site 2 (Table 2). The results in Table 2 have to be treated cautiously because of low sample number at some sites, however some patterns emerge. The coefficients of variation were generally similar between neighbouring sites, which suggests the variation around a mean was similar across short distances. The mean size and 95th percentile value can vary greatly between sites at some but not all Masig locations.

\section{Relationship between sponge abundance and size}

There was no significant relationship between the abundance and size of Coscinoderma matthewsi in Torres Strait (Fig. 5). At sites where C. matthewsi was uncommon ( $\leq 2$ individuals), for example, mean size ranged from 3 to $25 \mathrm{~cm}$. At Masig, sponge abundance did not correlate with sponge size (Fig. 5),
Table 2. Coscinoderma matthewsi. Size distribution variables between sites at Masig locations showing sample number $(\mathrm{N})$, mean size, SD, coefficient of variation (CV) and the 95th percentile (95th); all measurements in $\mathrm{cm}$. Only locations where both sites had $\geq 10$ individuals were compared

\begin{tabular}{|lccrrrr|}
\hline \multirow{2}{*}{ Location } & Site & N & Mean & SD & CV & 95 th \\
\hline 2 & 1 & 20 & 13.9 & 5.8 & 0.4 & 21.2 \\
& 2 & 14 & 6.4 & 3.3 & 0.5 & 10.7 \\
3 & 1 & 33 & 8.5 & 4.9 & 0.6 & 18.0 \\
& 2 & 12 & 9.3 & 8.7 & 0.9 & 23.7 \\
4 & 1 & 21 & 9.0 & 4.8 & 0.5 & 15.0 \\
& 2 & 32 & 12.3 & 7.8 & 0.6 & 25.0 \\
5 & 1 & 20 & 9.9 & 5.6 & 0.6 & 18.3 \\
& 2 & 20 & 7.4 & 3.3 & 0.5 & 12.1 \\
6 & 1 & 12 & 13.8 & 8.4 & 0.6 & 27.3 \\
& 2 & 17 & 12.5 & 4.6 & 0.4 & 18.8 \\
\hline
\end{tabular}

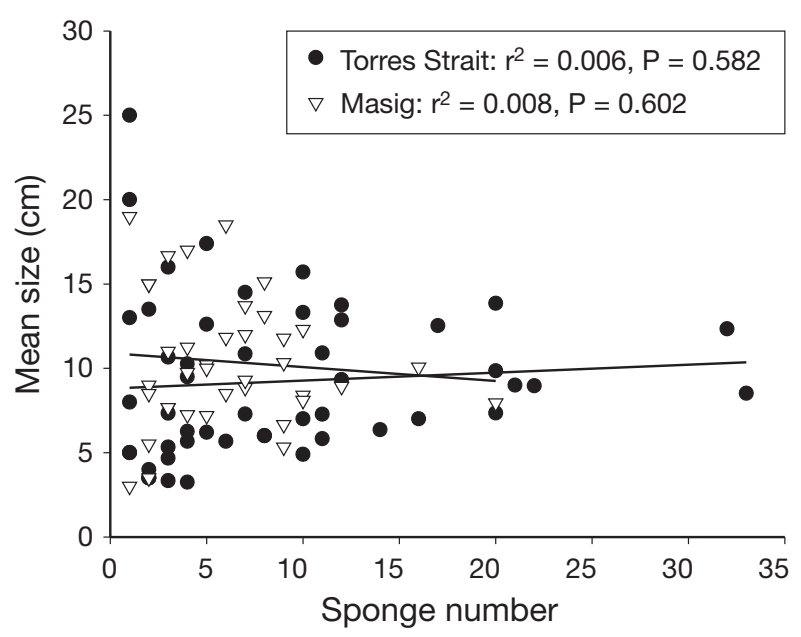

Fig. 5. Coscinoderma matthewsi. Linear regression between sponge number and mean size of sponges at each site in Torres Strait $(\bullet)$ and at each transect at Masig $(\nabla)$

\section{DISCUSSION}

We surveyed reefs in the central and eastern Torres Strait. Those around Masig have the highest abundance of Coscinoderma matthewsi, which supports the findings from a survey in 2004 (Duckworth et al. 2008). The mean abundance of C. matthewsi $30 \mathrm{~m}^{-2}$ at Masig in the present study (5.5 individuals [ind.]) was similar to that recorded in 2005 (5.3 ind., Duckworth \& Wolff 2007b) but higher than in 2004 (2.8 ind.). For Erub, which was also included in the 2004 survey, mean C. matthewsi abundance was more than $10 \times$ greater than in 2007 (1.1 ind. $30 \mathrm{~m}^{-2}$ ) than in 2004 (0.08 ind.). Variation in abundance between studies at Masig and Erub probably results from different locations monitored in 2004 and 2007 (i.e. spatial component) and successful recruitment pulses between survey years (temporal component). A separate study that 
monitored the population dynamics of $C$. matthewsi at Masig has found that its recruitment to coral reefs varies between years (A. R. Duckworth unpubl. data), which is typical of many sessile invertebrates (Wallace 1985, Coles \& Brown 2007).

The high abundance of Coscinoderma matthewsi at Masig results from the interaction of biotic and abiotic processes promoting the survival of all life-stages at this central Torres Strait island group. Some biotic and abiotic factors that can influence sponge distribution and abundance patterns include disease (Ayling 1981), predation (Randall \& Hartman 1968, Ayling 1978), reef slope (Bell \& Smith 2004) and substrate composition (Trautman et al. 2003). Reef slope greatly influences abundances of $C$. matthewsi, with more individuals found on steep slopes (Duckworth et al. 2008). In Torres Strait, river plume water from neighbouring Papua New Guinea and currents trapping sediments around islands and reefs (Wolanski et al. 1984) result in relatively turbid waters, with horizontal visibility averaging $8 \mathrm{~m}$ (Duckworth et al. 2008). High levels of sediment can reduce sponge pumping rates (Gerrodette \& Flechsig 1979) and negatively affect sponge growth (Wilkinson \& Vacelet 1979, Duckworth et al. 2003). It is therefore likely that higher abundance of $C$. matthewsi on steep reef results, in part, from lower levels of sedimentation.

Water movement between and within island groups could also affect the transport of Coscinoderma matthewsi larvae and subsequent settlement and recruitment onto Torres Strait coral reefs. Demospongiae of the order Dictyoceratida like C. matthewsi typically produce well-developed larvae that settle within a few hours (Maldonado \& Young 1996). The formation of eddies around Torres Strait islands and reefs (Wolanski et al. 1984) could trap larvae, cause patchy settlement and promote variation in the abundance of $C$. matthewsi recruits over small spatial distances

Water movement can also affect the growth and final size of heterotrophic sponges by influencing the availability of food particles (Wilkinson \& Vacelet 1979, Duckworth et al. 2004), typically bacteria and microalgae (Reiswig 1971, Pile et al. 1996). Water movement can vary greatly between neighbouring reefs and islands in Torres Strait (Wolanski \& Ruddick 1981), probably promoting spatial variation in growth of Coscinoderma matthewsi (Duckworth et al. 2007b) and causing mean size and expected maximum size (95th percentile) to vary over small and large spatial scales.

At all island groups, the size frequency distributions of Coscinoderma matthewsi were positively skewed; thus, small individuals dominated island populations. Positively skewed size patterns have been recorded for other sponge species (Meroz \& Ilan 1995, Trautman et al. 2000), while some sponge populations are domi- nated by large individuals (López-Victoria \& Zea 2005). For C. matthewsi, the level of skewness (on untransformed data) varied among island groups, with the highest occurring at Ugar and Masig. Size patterns and skewness values of many coral species vary across space, resulting from differences in the intensity of and interaction between abiotic and biotic factors (Bak \& Meesters 1998, Meesters et al. 2001, Richardson \& Voss 2005). For C. matthewsi, spatial variation in food availability, recruitment and the availability of steep rocky reef to provide both stable substrate for growth and reduce sediment smothering, could all contribute to differences in size patterns among island groups and between sites. Similar to many coral species (Bak \& Meesters 1998, Meesters et al. 2001), log-transforming the size data for C. matthewsi generally reduced asymmetry, resulting in normalised distributions of size for populations at each island group. Differences in mean size of $C$. matthewsi between island groups were small compared with many coral species (Bak \& Meesters 1998), relating to the relatively smaller size of C. matthewsi compared with most corals.

Factors that promote high abundance of Coscin oderma matthewsi in Torres Strait may not necessarily promote its growth and final size. This view is supported by the missing correlation between abundance and size. Because sponges have indeterminate growth, where final size is influenced more by ambient conditions than genetics (Sebens 1987), it could result in locations or sites containing a high abundance of longlived but small sponges. Individuals of $C$. matthewsi in Torres Straight are expected to reach an age of $>10 \mathrm{yr}$ (Duckworth et al. 2007a). Favourable conditions combined with low levels of disturbance, however, can promote sponge survival and growth, resulting in localised patches where $C$. matthewsi is both large and abundant (Duckworth \& Wolff 2007b).

Acknowledgements. We thank J. Morris, S.. Lowatta, S. Lui, T. Hyndes, E. Matson and the crew of the RV 'Cape Ferguson' who helped out with the diving and field work for this study. We also thank the indigenous communities at Ugar, Erub, Masig, Poruma and Warraber islands for allowing us to conduct this study in their traditional sea country. The Australian Institute of Marine Science, Torres Strait Regional Authority and the Australian government's Marine and Tropical Science Research Facility funded this study.

\section{LITERATURE CITED}

Aerts LAM (1998) Sponge/coral interactions in Caribbean reefs: analysis of overgrowth patterns in relation to species identity and cover. Mar Ecol Prog Ser 175:241-249

Ayling AL (1978) The relationship of food availability and food preferences to the field diet of an echinoid Evechinus chloroticus (Valenciennes). J Exp Mar Biol Ecol 33:223-235

Ayling AM (1981) The role of biological disturbance in temperate subtidal encrusting communities. Ecology 62:830-847 
Bak RPM, Meesters EH (1998) Coral population structure: the hidden information of colony size-frequency distributions. Mar Ecol Prog Ser 162:301-306

Bell JJ, Smith D (2004) Ecology of sponge assemblages (Porifera) in the Wakatobi region, south-east Sulawesi, Indonesia: richness and abundance. J Mar Biol Assoc UK 84:581-591

Bergquist PR (1995) Dictyoceratida, Dendroceratida and Verongida from the New Caledonia Lagoon (Porifera: Demospongiae). Mem Queensl Mus 38:1-51

Coles SL, Brown EK (2007) Twenty-five years of change in coral coverage on a hurricane impacted reef in Hawai'i: the importance of recruitment. Coral Reefs 26:705-717

$>$ Duckworth AR, Wolff CW (2007a) Bath sponge aquaculture in Torres Strait, Australia: effect of explant size, farming method and the environment on culture success. Aquaculture 271:188-195

Duckworth AR, Wolff CW (2007b) Patterns of abundance and size of Dictyoceratid sponges among neighbouring islands in central Torres Strait, Australia. Mar Freshw Res 58: 204-212

Duckworth AR, Samples GA, Wright AE, Pomponi SA (2003) In vitro culture of the tropical sponge Axinella corrugata (Demospongiae): effect of food cell concentration on growth, clearance rate, and biosynthesis of stevensine. Mar Biotechnol 5:519-527

Duckworth AR, Battershill CN, Schiel DR (2004) Effects of depth and water flow on growth, survival and bioactivity of two temperate sponges cultured in different seasons. Aquaculture 242:237-250

Duckworth AR, Wolff C, Cobb R, Webster N (2007a) Ecological role and potential value of sponges to Torres Strait. Marine and Tropical Sciences Research Facility, Cairns

Duckworth AR, Wolff C, Evans-Illidge E, Morris J and others (2007b) Exploring the potential of bath sponge aquaculture in Torres Strait. CRC Proj Rep T1.6A, Townsville

> Duckworth AR, Wolff CW, Evans E, Whalan S, Lui S (2008) Spatial variability in community structure of Dictyoceratida sponges across Torres Strait, Australia. Cont Shelf Res 28:2168-2173

Dunlap M, Pawlik JR (1998) Spongivory by parrotfish in Florida mangrove and reef habitats. PSZN I: Mar Ecol 19: 325-337

Fromont J (2003) Porifera (sponges) in the Dampier Archipelago: taxonomic affinities and biogeography. In: Wells FE, Walker DI, Jones DS (eds) The marine flora and fauna of Dampier, Western Australia. Western Australian Museum, Perth, p 405-417

Gerrodette T, Flechsig AO (1979) Sediment-induced reduction in the pumping rate of the tropical sponge Verongia lacunosa. Mar Biol 55:103-110

> Harris PT (1988) Sediments, bedforms and bedload transport pathways on the continental shelf adjacent to Torres Strait, Australia - Papua New Guinea. Cont Shelf Res 8: 979-1003

Lesser MP (2006) Benthic-pelagic coupling on coral reefs: feeding and growth of Caribbean sponges. J Exp Mar Biol Ecol 328:277-288

López-Victoria M, Zea S (2005) Current trends of space occupation by encrusting excavating sponges on Colombian coral reefs. PSZN I: Mar Ecol 26:33-41
MacMillan SM (1996) Starting a successful commercial sponge aquaculture farm. Center for Tropical and Subtropical Aquaculture, University of Hawaii

Maldonado M, Young CM (1996) Effects of physical factors on larval behaviour, settlement and recruitment of four tropical demosponges. Mar Ecol Prog Ser 138:169-180

- Meesters EH, Hilterman M, Kardinaal E, Keetman M, de Vries M, Bak RPM (2001) Colony size-frequency distributions of scleractinian coral populations: spatial and interspecific variation. Mar Ecol Prog Ser 209:43-54

> Meroz E, Ilan M (1995) Life history characteristics of a coral reef sponge. Mar Biol 124:443-451

> Pile AJ, Patterson MR, Witman JD (1996) In situ grazing on plankton $<10 \mu \mathrm{m}$ by the boreal sponge Mycale lingua. Mar Ecol Prog Ser 141:95-102

> Randall JE, Hartman WD (1968) Sponge-feeding fishes of the West Indies. Mar Biol 1:216-225

Reiswig HM (1971) Particle feeding in natural populations of three marine demosponges. Biol Bull (Woods Hole) 141: 568-591

Reiswig HM (1973) Population dynamics of three Jamaican Demospongiae. Bull Mar Sci 23:191-226

- Richardson LL, Voss JD (2005) Changes in a coral population on reefs of the northern Florida Keys following a coral disease epizootic. Mar Ecol Prog Ser 297:147-156

Sebens KP (1987) The ecology of indeterminate growth in animals. Annu Rev Ecol Syst 18:371-407

Soong K (1993) Colony size as a species character in massive reef corals. Coral Reefs 12:77-83

- Trautman DA, Hinde R, Borowitzka MA (2000) Population dynamics of an association between a coral reef sponge and a red macroalga. J Exp Mar Biol Ecol 244:87-105

Trautman DA, Hinde R, Borowitzka MA (2003) The role of habitat in determining the distribution of a sponge-red alga symbiosis on a coral reef. J Exp Mar Biol Ecol 283:1-20

Vermeij MJA, Bak RPM (2003) Species-specific population structure of closely related coral morphospecies along a depth gradient (5-60 m) over a Caribbean reef slope. Bull Mar Sci 73:725-744

- Wallace CC (1985) Seasonal peaks and annual fluctuations in recruitment of juvenile scleractinian corals. Mar Ecol Prog Ser 21:289-298

> Wilkinson CR (1983) Net primary productivity in coral reef sponges. Science 219:410-412

Wilkinson CR, Cheshire AC (1989) Patterns in the distribution of sponge populations across the central Great Barrier Reef. Coral Reefs 8:127-134

> Wilkinson CR, Evans E (1989) Sponge distribution across Davies Reef, Great Barrier Reef, relative to location, depth, and water movement. Coral Reefs 8:1-7

Wilkinson CR, Vacelet J (1979) Transplantation of marine sponges to different conditions of light and current. J Exp Mar Biol Ecol 37:91-104

> Wolanski E, Ruddick B (1981) Water circulation and shelf waves in the northern Great Barrier Reef Lagoon. Aust J Mar Freshw Res 32:721-740

> Wolanski E, Pickard GL, Jupp DLB (1984) River plume, coral reefs and mixing in the Gulf of Papua and the northern Great Barrier Reef. Estuar Coast Shelf Sci 18:291-314

Zar JH (1999) Biostatistical analysis, 4th edn. Prentice Hall, Upper Saddle River, NJ

Submitted: April 14, 2007; Accepted: September 3, 2008 Proofs received from author(s): November 13, 2009
Editorial responsibility: Peter Edmunds, Northridge, California, USA 